\title{
ANALISIS KEBIJAKAN POLITIK HUKUM PEMERINTAH KOTA CILEGON ATAS PENINGKATAN PEMBANGUNAN EKONOMI TAHUN 2010-2015
}

\author{
Malik Fatoni, Surachman \\ STIE Bina Bangsa | Jl. Raya Serang-Jakarta Km.03 No.0 I B. Pakupatan,Serang-Banten \\ ton_bmd@yahoo.com
}

\begin{abstract}
This article examines the effectiveness of making and stipulating regulations and legislation on efforts to increase economic development in Cilegon. Efforts to get achievements and progress for increasing economic development are necessary to conduct policy analysis on matters relating to political and legal policies and then to conduct a review of documents, observations and interviews. The legal political policy carried out by the Government of Cilegon can push for an increase in regional economic development. This can be seen from the legislative products validated by the Regional Legislative Assembly of Cilegon. Moreover, the quality and quantity are so good that the products can be carried out well by the executive and provide juridical power for the Government of Cilegon in increasing economic development as seen from the indicators of increasing economic development itself. Legal political policies that are processed and in synergy between government institutions in Cilegon indicate a strong and large commitment from these institutions to encourage and improve economic development in a sustainable and measurable manner.
\end{abstract}

Keywords: Politics of Law, Regional Government, Economic Development.

Abstrak: Artikel ini mengkaji tentang efektifitas pembuatan dan penetapan regulasi dan peraturan perundang-undangan terhadap upaya peningkatan pembangunan ekonomi di kota cilegon. Upaya untuk mendapatkan capaian dan progress bagi peningkatan pembangunan ekonomi, perlu dilakukan analisis kebijakan terhadap hal yang menyangkut kebijakan politik dan hukum untuk kemudian dilakukan sebuah penelaahan terhadap dokumen, observasi dan wawancara. Kebijakan politik hukum yang dilakukan oleh Pemerintah Kota Cilegon 
dapat mendorong atas terjadinya peningkatan pembangunan ekonomi daerah, hal ini terlihat dari produk legislasi yang di sah kan oleh DPRD Kota Cilegon secara kualitas dan kuantitas sudah sangat baik sehingga produk tersebut dapat dilaksanakan dengan baik oleh eksekutif dan memberikan kekuatan yuridis bagi Pemerintah Kota Cilegon dalam peningkatan pembangunan ekonomi, sebagaimana terlihat dari indicator peningkatan pembangunan ekonomi itu sendiri. Kebijakan politik hukum yang diolah dan di proses secara sinergis antar lembaga-lembaga pemerintahan yang ada di Kota Cilegon, mengindikasikan komitmen yang kuat dan besar dari lembaga-lembaga tersebut untuk mendorong dan meningkatkan pembangunan ekonomi secara berkesinambungan dan terukur.

Kata Kunci: Politik Hukum, Pemerintahan Daerah, Pembangunan Ekonomi.

\section{Pendahuluan}

Pembangunan ekonomi sesungguhnya adalah suatu proses kerja konkrit dan nyata apa yang dilakukan oleh pemerintah baik pusat dan daerah untuk mempercepat dan mewujudkan kesejahteraan rakyat secara merata dan berkeadilan. Tetapi dalam upaya memacu pembangunan ekonomi tersebut sedikitnya banyak mendapatkan hambatan dan bahkan memunculkan persoalanpersoalan baru yang mengganggu kenyamanan dan ketentraman kehidupan masyarakat. Persoalan tersebut muncul tatkala didapati adanya regulasi kebijakan dan beberapa peraturan yang dibuat pemerintah daerah tumpang tindih dengan peraturan yang ada di pusat. Sehingga kepastian hukum yang hendak di capai tidak dapat terwujud seraya terdapatnya sejumlah kompleksitas politik yang terjadi mengiring berbagai persoalan di daerah menjadi salah satu hambatan yang memicu persoalan baru bagi upaya pemerintahan daerah untuk mempercepat peningkatan pembangunan ekonomi.

Sungguhpun dalam kehidupan masyarakat yang berhubungan dengan ekonomi tidak bisa terpisahkan dengan kehidupan politik. Dalam perjalanannya dua dimensi ini memiliki keterkaitan dan berjalan saling beriringan. Negara sebagai system politik memiliki kewenangan yaitu berupa penggunaan kekuasaan 
dengan memaksa secara sah dalam batas dan toleransi kepada masyarakat secara keseluruhan untuk mengatur kehidupan masyarakat, sementara disisi lain negara sebagai system ekonomi merupakan system pengorganisasian pemenuhan kebutuhan masyarakat terhadap barang dan jasa agar tersedia secara simultan dan dapat diperoleh dengan mudah oleh masyarakat. ${ }^{1}$

Keadaan ini cukup banyak di alami oleh beberapa daerah di Indonesia termasuk persoalan yang kerap di alami oleh pemerintah daerah kota Cilegon dalam lima tahun terakhir ini. Pemerintahan daerah dengan otoritasnya harus mampu mengambil satu kebijakan yang strategis dan objektif dalam upaya peningkatan pembangunan ekonomi. Pengambilan keputusan atas kebijakan ini haruslah The causes of policy failure, at root, political. Artinya bahwa siapapun pemerintah dan pemimpin yan berkuasa bahwa dia harus sadar akan upaya mengambil satu kebijakan yang baik perlu dilandasi oleh kesadaran politik yang memang memiliki tujuan yang ideal untuk menciptakan kehidupan masyarakat yang lebih sejahtera dibanding keadaan sebelumnya dan bermanfaat semua orang. ${ }^{2}$ Untuk itu peranan pemerintah sebagaimana amanat Undang-Undang no 32 tahun 2004 tentang Pemerintahan Daerah, mengamanatkan bahwa daerah diberikan kewenangan yang cukup luas untuk dapat memaksimalkan pengelolaan kekayaan dan aset daerah sebagai basis pertumbuhan ekonomi daerah untuk mendukung peningkatan pertumbuhan pembangunan ekonominya.

Beberapa persoalan yang timbul dalam implementasi pelaksanaan undang-undang nomor 32 tahun 2004 tersebut jika dikaitkan dengan kebijakan politik hukum di satu pemerintahan daerah adalah sebagai berikut

'Arbi Sanit, Sistem Politik Indonesial Kestabilan, Peta Kekuatan Politik dan Pembangunan, (Jakarta: Raja Grafindo Persada, 2012).

${ }^{2}$ Noeng Muhadjir, Metodologi Penelitian Kebijakan dan Evaluation Research, (Yogyakarta: Rake Sarasin, 2004). 
a. Pola komunikasi birokrasi yang masih sering mengalami kebuntuan dan beropetensi menjadi konflik kepentingan

b. Masih minimnya regulasi seperti perda-perda yang dihasilkan dalam upaya menopang kegiatan program peningkatan pembangunan ekonomi

c. Penempatan porsi jabatan-jabatan dalam birokrasi yang tidak sesuai dengan kompetensinya sehingga memunculkan inkonsistensi kebijakan

d. Terbitnya beberapa kebijakan politik dan hukum didapati tidak efektif dan efisien yang mengakibatkan tertundanya beberapa program dan arah kebijakan peningkatan pembangunan ekonomi.

Melihat realitas yang ada, sesungguhnya keadaan dan situasi yang dialami pemerintahan kota cilegon tidak jauh berbeda dengan beberapa masalah yang jelaskan tersebut di atas, sehingga peneliti memiliki minat untuk mengeksplore, menguraikan dan menjabarkan secara akademis dari sudut pandang kebijakan politik dan hukum dari suatu permasalahan tentang pembangunan ekonomi yang sudah dan sedang berjalan yang bermuara pada kesejahteraan rakyat. Untuk itu, dalam tulisan ini penulis mengkaji tentang Kebijakan Politik Hukum Pemerintah Daerah Kota Cilegon Terhadap Peningkatan Pembangunan Ekonomi Tahun 2010-2015.

\section{Kebijakan Politik Dan Hukum}

Kebijakan, politik dan hukum memiliki definisi yang berbeda, namun istilah ini memiliki hubungan erat dengan konsep pemerintahan dan kelembagaan dalam suatu organisasi atau institusi yang bisa di integrasikan. Kebijakan adalah rangkaian konsep dan asas yang menjadi pedoman dan dasar rencana dalam pelaksanaan suatu pekerjaan, kepemimpinan, dan cara bertindak. Istilah ini dapat diterapkan pada pemerintahan, organisasi dan kelompok sektor swasta, serta individu.

Kebijakan sendiri berkaitan erat dengan peningkatan pembangunan ekonomi dan kesejahteraaan rakyat karena hal itu 
sering disebut dengan Public Policy. Public Policy sendiri dimaknai sebagai suatu kebijakan bagi kepentingan rata-rata penduduk. Seperti kebijakan tarif transportasi, harga BBM, retribusi pasar dan sebagainya. ${ }^{3}$

Definisi kebijakan sendiri antara lain dapat kita ketahui dari beberapa pendapat para ahli, antara lain Soeharto, beliau memberikan pemahaman apa sesungguhnya kebijakan, yaitu seperangkat tindakan (Course of Action), kerangka kerja (Framework), petunjuk (Guideline), Rencana (Plan), Peta (Map), atau strategi yang dirancang untuk menterjemahkan visi dan misi dan apa yang hendak ingin direncanakan dan dilaksanakan oleh suatu lembaga. ${ }^{4}$

Mustopadidjaja menjelaskan, bahwa istilah kebijakan lazim digunakan dalam kaitannya atau kegiatan pemerintah, serta perilaku negara pada umumnya dan kebijakan tersebut dituangkan dalam berbagai bentuk peraturan. ${ }^{5}$

Makna kebijakan di atas, berupa tindakan yang dilakukan langkah demi langkah menunjukan tindakan yang berpola, hal itu sejalan dengan pandangan Solichin Abdul Wahab yang menegaskan bahwa:"Policy itu adalah suatu tindakan berpola yang mengarah pada tujuan tertentu dan bukan sekedar keputusan untuk melakukan sesuatu" ${ }^{6}$

Carl J Federick sebagaimana dikutip Leo Agustino mendefinisikan kebijakan sebagai serangkaian tindakan/kegiatan yang diusulkan seseorang, kelompok atau pemerintah dalam suatu lingkungan tertentu dimana terdapat hambatan-hambatan (kesulitan-kesulitan) dan kesempatan-kesempatan terhadap

${ }^{3}$ Noeng Muhadjir, Kebijakan dan Perencanaan Sosial; Pengembangan Sumber Daya Manusia, (Yogyakarta: Rake Sarasin, 2000).

${ }^{4}$ Edi Suharto, Membangun Masyarakat Memberdayakan Masyarkat; Kajian Strategis Pembengunan Kesejahteraan Sosial dan Pekerjaan Sosial, (Bandung: Refika Aditama, 2009), 107.

${ }^{5}$ Arifin Tahir, Kebijakan Publik \& Transparansi Penyelenggaran Pemerintah Daerah, (Bandung: Penerbit Alfabeta, 20I4), 21.

${ }^{6}$ Abdul Solichin Wahab, Analisis Kebijakan, dari Formulasi ke Penyusunan Model-model Implementasi Kebijakan Publik, (Jakarta: Bumi Aksara, 200I), 3. 
pelaksanaan usulan kebijaksanaan tersebut dalam rangka mencapai tujuan tertentu. ${ }^{7}$

Winarno memahami Kebijakan sering digunakan untuk menunjuk perilaku seorang aktor (misalnya seorang pejabat, suatu kelompok, maupun suatu lembaga pemerintah) atau sejumlah aktor dalam suatu bidang kegiatan tertentu. ${ }^{8}$

Sedangkan menurut William N. Dunn, Kebijakan Publik (Public Policy) adalah Pola ketergantungan yang kompleks dari pilihan-pilihan kolektif yang saling tergantung, termasuk keputusan-keputusan untuk tidak bertindak, yang dibuat oleh badan atau kantor pemerintah. ${ }^{9}$

Atas dasar beberapa pengertian di atas dapatlah disimpulkan bahwa kebijakan adalah serangkaian proses kolekti yang berupa tindakan atau kegiatan seseorang dalam sistem kelembagaan untuk memilih atas dasar pilihan untuk membuat dan merumuskan suatu keputusan dalam kegiatan tertetntu untuk mencapai suatu tujuan.

Sementara pemaknaan atas kebijakan politik hukum sendri sebagaimana di ungkapkan oleh Padmo Wahjono, bahwa Politik Hukum adalah kebijakan penyelenggara negara yang bersifat mendasar dalam menentukan arah, bentuk maupun isi daripada hukum yang akan dibentuk dan tentang apa yang dijadikan kriteria untuk menghukumkan sesuatu. ${ }^{10}$

Sedangkan Satjipto Rahardjo mendefinisikan politik hukum sebagai aktivitas memilih dan cara yang hendak dipakai untuk mencapai suatu tujuan sosial dan hukum tertentu dalam masyarakat. ${ }^{11}$ Dan adapun menurut Mahfud MD, politik hukum

${ }^{7}$ Leo Agustion, Dasar-Dasar Kebijakan Publik, (Bandung, Alfabet: 2008), 7.

${ }^{8}$ Budi Winarno, Teori dan Proses kebijakan Publik, (Yogyakarta: Media Pressindo, 2012), 14.

'William N Dunn, Pengantar Analisis Kebijakan Publik, Edisi Revisi (Yogyakarta: Gajah Mada University, 2003), 132.

IOPadmo Wahyono, Indonesia Negara Berdasarkan Atas Hukum, Cet. II, (Jakarta: Ghalia Indonesia, 1986), 16.

"Satjipto Raharjo, IImu Hukum, (Bandung: Citra Aditya Bakti, 2000), 35. 
adalah kebijakan hukum (legal policy) yang hendak diterapkan atau dilaksanakan oleh suatu pemerintahan negara tertentu. ${ }^{12}$

Definisi diatas dapatlah dipahami dalam kesimpulan bahwa politik hukum bertugas untuk meneliti perubahan - perubahan mana yang perlu diadakan terhadap hukum yang ada agar memenuhi kebutuhan-kebutuhan baru di dalam kehidupan masyarakat.

Dengan kata lain apa yang bisa kita pahami dengan kebijakan politik hukum itu adalah sebuah rangkaian dalam menentukan sebuah pilihan yang terkait dalam suatu pengambilan keputusan atau kebijakan tentang cara-cara dan tujuan yang akan dicapai dari tujuan hukum yang berlaku dimasyarakat. Untuk mencapai tujuan hukum tersebut hendaklah memperhatikan beberapa indicator dari factor politik hukum itu, yakni ide yang dicita-cita dari negara, kehendak pembentuk Undang-undang, Praktisi hukum, teoritis hukum, perkembangan hukum negara lain, perkembangan hukum Internasional.

\section{Pemerintahan Daerah}

Pasal 1 angka 2 Undang-Undang Nomor 32 Tahun 2004 tentang Pemerintah Daerah menjelaskan bahwa yang dimaksud pemerintahan daerah adalah penyelenggaraan urusan pemerintahan oleh pemerintah daerah dan DPRD menurut asas otonomi dan tugas pembantuan dengan prinsip otonomi seluasluasnya dalam sistem dan prinsip Negara Kesatuan Republik Indonesia sebagaimana dimaksud dalam Undang-Undang Dasar Negara Republik Indonesia 1945.

Fungsi pemerintahan daerah sendiri adalah turut menciptakan pemerintahan yang stabil; pengawasan jalannya pemerintahan di daerah secara efektif dan efisien; memelihara kepentingan, keamanan dan ketertiban umum serta memajukan kesejahteraan rakyat. Selain itu untuk membentuk pemerintahan yang

\footnotetext{
12Moh. Mahfud MD, Membangun Politik Menegakkan Konstitusi, (Jakarta: Rajawali Pers, 20 I0), I .
} 
mencerminkan kehendak rakyat berdasar prinsip kemandirian politik, ekonomi dan kebudayaan

Seorang pakar Otonomi Daerah mendefinisikan apa itu pemerintahan daerah sebagai kegiatan penyelenggaraan negara guna memberikan pelayanan dan perlindungan bagi segenap warga masyarakat, melakukan pengaturan, mobilisasi semua sumber daya yang diperlukan, serta membina hubungan baik di dalam lingkungan negara ataupun dengan negara lain. Di tingkat lokal tentu saja membina hubungan dengan pemerintahan nasional dan pemerintahan daerah yang lainya. ${ }^{13}$

Pemerintahan Daerah sendiri adalah pemerintahan yang berbasis pada desenttralisasi yaitu penyerahan wewenang pemerintahan oleh Pusat kepada daerah otonom untuk mengatur dan mengurus kepentingan masyarakat setempat, sifatnya adalah pendelagasian yang mencakup kewenangan politik, kewenangan urusan daerah dan kewenangan pengelolaaan keuangan. ${ }^{14}$

Atas penjelasan diatas kesimpulan yang bisa didapatkan adalah bahwa penyelenggaraan pemerintahan di daerah yang memegang kendali kekuasaan di daerah dengan tujuan melaksanakan dan menyelenggara kegiatan Pemerintahan Daerah dalam wujud kekuasaan otonom.

\section{Pembangunan Ekonomi}

Pembangunan Ekonomi adalah suatu proses yang menyebabkan pendapatan perkapita penduduk suatu masyarakat meningkat dalam jangka panjang dengan perubahan ciri-ciri penting suatu masyarakat, yaitu perubahan baik dalam hal teknologi, pola pikir masyarakat maupun kelembagaan. ${ }^{15}$

Konsep lain dikemukakan oleh Rokhimin Dahuri (2004) tentang apa itu pembangunan ekonomi daerah : "sebagai proses dimana pemerintah daerah dan masyarakatnya mengelola

${ }^{13}$ Riyas Rasyid, O tonomi Daerah Dalam Negara Kesatuan, (Yogyakarta: Pustaka Pelajar, 2002), 8. ${ }^{14}$ HAW. Widjaya, Penyelenggaraan O tonomi di Indoensia, (Jakarta: Raja Grafindo Persada, 2009), 12.

${ }^{15}$ Safril, dkk., Ekonomi dan Pembangunan, (Jakarta: Bumi Aksara, 2003), 24. 
sumberdaya-sumberdaya yang ada dan membentuk suatu pola kementrian antara pemerintah daerah dengan sector swasta untuk menciptakan suatu lapangan kerja baru dan merangsang perkembangan kegiatan ekonomi (pertumbuhan ekonomi) dalam wilayah tersebut. ${ }^{16}$

Untuk itu setiap pembangunan ekonomi bergantung dari pertumbuhan ekonomi (economic growth) dimana pembangunan ekonomi mendorong dalam tumbuhnya ekonomi dan sebaliknya pula, ekonomi memperlancar dalam proses pembangunan ekonomi. Jika pertumbuhan ekonomi peningkat maka akan terjadi peningkatan pula terhadap pembangunan ekonomi dan berdampak pada peningkatan kesejahteraan rakyat

Salah satu pemicu upaya meningkatkan pembangunan ekonomi setidaknya harus memperhatikan beberapa factor, yaitu factor ekonomi yang meliputi aspek, ketersediaan sumber daya manusia dan pemanfaatan serta pengelolaan sumber daya alamnya. Sementara factor non-ekonomi antara lain meliputi kondisi sosial kultur yang ada di masyarakat, keadaan politik, kelembagaan, dan sistem yang berkembang dan berlaku. Pembangunan itu sendiri sesungguhnya pembicaraan yang terkait dengan perubahan sosial, saat dimana masyarakat bergerak maju maka disitulah pemaknaan pembangunan muncul, karena pembangunan merupakan suatu usaha yang tanpa akhir.

Dari perspektif inilah dapat disimpulkan apa sesungguhnya pembangunan ekonomi itu. Pembangunan ekonomi dipahami dan dipandang sebagai kenaikan dalam pendapatan perkapita, karena ini merupakan sebagai suatu pencerminan dari timbulnya perbaikan dalam peningkatan perekonomian masyarakat. suatu bentuk perubahan yang terjadi secara terus-menerus melalui serangkaian kombinasi proses demi mencapai sesuatu yang lebih baik yaitu adanya peningkatan pendapatan perkapita yang terus menerus berlangsung dalam jangka panjang.. Dan pembangunan

${ }^{16}$ wwan Nugroho, dan Rokhimin Dahuri, Pembangunan Wilayah perspektif Ekonomi, Sosial, dan Lingkungan, (Jakarta: LP3ES, 2004), 47. 
ekonomi juga hendaknya di upayakan dan diarahkan untuk mencapai suatu kesejahteraan rakyat sebagaimana yang diamanatkan oleh UUD 1945.

\section{Kebijakan Politik Hukum}

DPRD kota Cilegon sebagai lembaga legislatif mengambil peran yang sangat penting dalam mendukung proses kemajuan dan akselerasi peningkatan ekonomi daerah pasca ditetapkannya suatu daerah sebagai otonom baru. Kota Cilegon sendiri ditetapkan sebagai daerah kota otonom baru pada 27 April 1999 berdasarkan UU No.15 Tahun 1999 tentang terbentuknya Kotamadya Daerah Tingkat II Depok dan Kotamadya Daerah Tingkat II Cilegon. Berdasarkan undang-undang ini mengamantakan beberapa point penting tentang hakikat dan tujuan utama dibentuknya daerah otonom baru yang tidak lain peningkatan pembangunan dan kesejahteraan rakyat dengan memanfaatkan potensi local dan pemberdayaan ekonomi. Indicator sebuah daerah dapat dikatakan berhasil adalah PDRB (Product Domestic Regional Bruto) Dan LPE (Laju Pertumbuhan Ekonomi), Yang Mengindikasikan Perbaikan, Penguatan dan Kemapanan Daerah dalam Penguatan Struktur Perekonomian Daerah.

Jika politik hukum dimaknai sebagai kebijaksanaan penyelenggara Negara tentang apa yang dijadikan criteria untuk menghukumkan sesuatu (menjadikan sesuatu sebagai Hukum). Kebijaksanaan tersebut dapat berkaitan dengan pembentukan hukum dan penerapannya. Maka apa yang dibahas dan disajikan dalam penelitian ini sebagai usaha untuk memperoleh gambaran tentang peranan sesungguhnya lembaga legislative dalam merancang, membahas dan mengesahkan berbagai produk perundang undangan yang dibutuhkan oleh pemerintah sebagai lembaga yang melaksankan perundang-undangan tersebut.

Jika semua produk hukum diasumsikan sebagai produk politik, maka konsep hukum yang dikatakan sebagai sebuah peraturan yang abstrak dapat dikristalisasikan oleh kebijakan yang 
bersifat politik. Hal ini sangat mungkin bisa dipahami karena kehendak politik sendiri sangat dinamis dan berinteraksi secara baik dengan situasi dan kondisi yang ada. Kristalisasi dari kehendak politik itu terlihat dari beberapa sidang yang dilakukan oleh parlemen dengan pemerintah dalam membuat undangundang atau peraturan perundangan lainnya. Gambaran perilaku di atas seungguhnya merupakan kontelasi dari upaya antara parlemen dengan pemerintah untuk memproleh produk hukum dari kebijakan politik yang dapat memenuhi keadilan dan sebanyak mungkin menyerap aspirasi masyarakat, karena produk hukumnya nanti digunakan dan dilaksanakan untuk kepentingan masyarakat pula.

Kebijakan politik hukum yang sesunguhnya terjadi seharusnya mengacu pada beberapa indikator penting, antara lain:

1) Proses penggalian nilai dan aspirasi yang berkembang di masyarakat

2) Penyelenggaraan negara yang berwenang dan memiliki otoritas penuh dapat merumuskan dan menetapkan politik hukumnya

3) Proses perdebatan dan perumusan nilai nilai dan aspirasi tersebut kedalam bentuk sebuah rancangan peraturan perundang undangan oleh penyelenggara negara yang berwenang merumuskan politik hukum

4) Pelaksanaan dari peraturan perundang undangan yang merupakan implementasi dari politik hukum suatu negara

Tentunya indikator di atas dapat berjalan dengan baik jika ada sinergisitas yang baik pula antara eksekutif dan legislative. Semua perencanaan dan pelaksanaan tata kelola pemerintahan yang baik menjadi pintu masuk bagi suksesnya pembangunan dan keberhasilan suatu pembangunan di daerah. Untuk itu pemerintahan Kota Cilegon dapat mengambil langkah-langkah progresif dan sistemik bagi upaya mewujudkan visi dan misi Kota Cilegon, visi dan misi itu perlu didukung oleh karena adanya : (1) Komitmen dari kepemimpinan daerah yang kuat dan demokratis; 
(2) Konsistensi kebijakan pemerintah; (3) Keberpihakan kepada rakyat; dan (4) Peran serta masyarakat dan dunia usaha secara aktif.

Jika mengingat kembali visi dan misi yang di gagas dan dituangkan dalam RPJP kota Cilegon tahun Tahun 2005-2025 “Pusat Industri, Perdagangan dan Jasa Terdepan di Pulau Jawa". RPJP ini pun menjadi pedoman di dalam penyusunan Rencana Pembangunan Jangka Menengah (RPJM) lima tahunan dan Rencana Kerja Pemerintah Daerah (RKPD) Kota Cilegon. Keberhasilan pembangunan daerah dalam mewujudkan visi Kota Cilegon, perlu didukung oleh: (1) Komitmen dari kepemimpinan daerah yang kuat dan demokratis; (2) Konsistensi kebijakan pemerintah; (3) Keberpihakan kepada rakyat; dan (4) Peran serta masyarakat dan dunia usaha secara aktif.

Berbicara mengenai kebijakan politik hukum pemerintahan kota Cilegon tidak lepas dari pola komunikasi dan sinergisitas yang telah dibangun antara eksekutif dan legeslatif. Harmonisasi hubungan ini terlihat dari komposisi politik secara kualitas jumlah anggota parlemen yang memiliki kesamaan warna dan ideology dari pendukung dan pengusung kekuasaan saat itu. Jumlah anggota DPRD Kota Cilegon periode 2014-2019 sebanyak 35 orang, sejumlah itu 11 orang berasala dari Partai Golkar, 4 dari PPP, 4 dari PDIP, 3 PAN, 3 PKS, 3 Gerindra, 4 Nasdem, 2 PKB dan 1 Demokrat. Komposisi ini jelas sangat memberikan keuntungan bagi pendukung kekuasaan yang menguasai 80 parlemen, sehingga jalannya komunikasi bisa berjalan dengan baik baik saat upaya eksekutif melakukan RDP atau kegiatan lainnya yang terkait dengan kebutuhan eksekutif.

Bila Kebijakan politik hukum sesungguhnya dipahami sebagai usaha kongkrit dan jelas yang dilakukan oleh pemerintah sebagai dasar pijakan dan alat (tool) untuk memperoses terbentuknya hukum yang dilakukan oleh lembaga otoritas dengan memperhatikan hakikat nilai hukum itu sendiri. Maka jelas apa yang dilakukan pemerintahan kota Cilegon untuk menjaga harmonisasi hubungan antara eksekutif dan legeslatif mutlak untuk 
di jaga dan dipertahankan. Karena semua rancangan program kegiatan yang di buat oleh eksekutif memerlukan legitimasi dan kekuatan yuridis formal dari parlemen.

Untuk itu fungsi dan peran parlemen tetap akan bersifat independen dan hubungan dengan aksekutif akan tetap bersifat koordinatif dan komunikatif, bukan lagi instruktif. Dalam menjalankan fungsi legislasinya DPRD kota Cilegon selama kurun waktu 2010-2015 dan mengacu pada UU No. 15 Tahun 1999 tersebut yaitu melakukan perencanaan dan pemantapan beberapa peraturan daerah yang di bicarakan bersama dengan pihak eksekutif telah menghasilkan produk hukum yang terbilang cukup baik. Sebagaimana keterangan tabel berikut:

Tabel. 1. Kualitas Produk Legilasi DPRD Kota Cilegon

\begin{tabular}{|l|l|l|}
\hline No & \multicolumn{1}{|c|}{ Tahun } & \multicolumn{1}{c|}{ Hasil Perda } \\
\hline 1. & 2010 & 7 Peraturan Daerah \\
\hline 2. & 2011 & 18 Peraturan Daerah \\
\hline 3. & 2012 & 16 Peraturan Daerah \\
\hline 4. & 2013 & 5 Peraturan Daerah \\
\hline 5. & 2014 & 10 Peraturan Daerah \\
\hline 6. & 2015 & 12 Peraturan Daerah \\
\hline
\end{tabular}

Untuk melihat lebih jauh bagaimana kebijakan politik hukum pemerintahan daerah kota cilegon, kita bisa melakukan analisis yang mendalam dari beberapa indicator penting, yakni proses penggalian nilai dan aspirasi yang berkembang di masyarakat.

Dalam menyusun peraturan daerah dimulai dari rancangan, pembahasan dan untuk sampai pada kata akhir pengesahan, semuanya mengacu pada peraturan yang ada antara lain

1) Undang-Undang No. 12 tahun 2011 tentang Pembentukan Peraturan Perundang-undangan

2) Undang- Undang No. 23 tahun 2014 tentang Pemerintahan Daerah

3) Peraturan Presiden No. 87 tahun 2014 tentang Peraturan Pelaksanaan Undang-Undang No. 12 tahun 2011 tentang Pembentukan Peraturan Perundang-undangan 
Sejumlah aturan itu dijelaskan bahwa mekanisme pembuatan suatu Raperda sampai pada Perda dimungkinkan haruslah melewati berbagai tahapan yaitu perencanaan, penyusunan, pembahasan, pengesahan, penetapan dan pengundangan. Dan kemudian langkah terakhir yang tidak kalah pentingnya adalah keterlibatan public dalam penyusunan PERDA.

Keterlibatan ini sebagai proses penggalian nilai dan aspirasi yang berkembang di masyarakat. Adapun bentuknya bisa melalui kunjungan kerja, rapat dengar pendapat, masukan secara lisan atau tulisan, seminar, lokakarya atau diskusi publik. Pentingnya usaha ini tidak lain untuk memudahkan publik dalam memberikan masukan secara lisan dan/atau tertulis, setiap Rancangan Peraturan Peraturan Daerah harus dapat diakses dengan mudah oleh masyarakat. Untuk itu proses penggalian nilai dan aspirasi yang berkembang di masyarakaat merupakan jalan konstitusional agar kelak nanti produk dari kebijakan politik hukum tersebut dapat dijalankan dengan baik dan menjadi acuan legal konstitusional bagi pelaksanaan sejumlah kebijakan lainnya.

Peningkatan peran serta dan partipasi masyarakat merupakan gambaran dari penguatan nilai-nilai atas demokrasi itu sendiri. Demokrasi sebagai system politik dan acuan dalam tata kelola kehidupan bernegara menekankan aspek keterlibatan masyarakat dalam kegiatan apapun. Semakin meningkat partisipasi masyarakat maka akan semakin kuat pula legitimasi pemerintahan untuk dapat bekerja secara optimal dalam upaya peningkatan pembangunan dan kesejahteraan rakyat.

Demokratisasi yang terjadi merupakan gambaran nyata bahwa interaksi antara politik dan hukum berjalan baik, artinya secara politik lembaga legislatif berperan penting dalam proses lagislasinya sampai pada terbentuknya suatu peraturan daerah, sementara eksekutif melalui biro hukum nya mengambil peran pada saat proses penyusunan dan perumusan atas produk hukum tertentu. Sehingga pola interkasi yang baik antara politik dan hukum ini akan melahirkan satu kebijakan yang kontrusktif dan 
tidak lagi bersifat desktruktif. Kebijakan ini lah yang kemudian sering dikonotasikan dengan kebijakan politik hukum.

Asumsi yang kemudian dibangun dari pemahaman demikian itu adalah bahwa legislasi sangat dipengaruhi oleh interaksi politik. Jika konfigurasi politik yang dianut suatu negara demokrastis maka dalam legislasinya akan memberi peranan besar dan partisipasi penuh kelompok sosial dan individu dalam masyarakat. Sebaliknya, jika konfigurasi politik yang dianut otoriter, maka peranan dan partisipasi masyarakat dalam legislasi relatif kecil. Hal demikian ini barang tentu juga terjadi dalam legislasi peraturan daerah (Perda)

Apa yang terjadi pada pemerintahan kota Cilegon antara tahun 2010-2015, sinergisitias yang dibangun begitu erat dan pola komunikasi dilakukan terjalin dengan baik dan dapat menjadi modal bagi terwujudnya sebuah produk hukum yang baik pula. Saat dimana sebuah produk kebijakan politik hukum diciptakan dalam suasana demokrasi yang baik, maka akan memberikan dampak besar pengaruh atas perubahan hidup masyarakat kearah yang lebih baik pula, kesenjangan ekonomi berkurang, ketidakdilan dalam penegakan hukum tidak terlihat lagi, kemiskinan dapat ditekan sampai pada angka yang realisitis.

Legislatif/parlemen adalah suatu tempat dimana secara formal masalah-masalah kemasyarakatan dibahas oleh anggota masyarakat. Karena anggota masyarakat terlibat didalam pembahasan itu, maka apapun yang diputuskan mengikat seluruh anggota masyarakat untuk melaksanakan. Karena fungsinya sebagai tempat berdiskusi seluruh anggota masyarakat, maka legislatif/parlemen harus:

a. Menggambarkan secara utuh kelompok yang ada dalam masyarakat,

b. Orang-orang yang terlibat di dalamnya memilliki keahlian minimal dan pengetahuan luas untuk memecahkan persoalan masyarakat, 
c. Anggota legislatif/parlemen harus mengutamakan kepentingan masyarakat dari pada kepentingan diri sendiri atau kelompoknya. ${ }^{17}$

Sementara posisi eksekutif dipahami dalam konteks pemerintahan adalah sebagai pembuat dan pelaksana dari peraturan perundang-undangan itu sendiri. Sehingga antara kedua lembaga tersebut dapat menjalin komunikasi yang baik dalam batasan yang sudah ditetapkan oleh undang-undang.

Hubungan Legislatif dan Eksekutif Daerah dalam proses perumusan Peraturan Daerah maka komunikasi yang sering dilakukan adalah komunikasi organisasi (antar organisasi) dan komunikasi antar pribadi (interpersonal). Miftah Toha menjelaskan komunikasi organisasi adalah suatu komunikasi yang terjadi dalam organisasi tertentu. Ciri dari komunikasi organisasi ini adalah berstruktur atau berhirarki. Komunikasi ini mempunyai struktur yang vertikal dan horizontal. Dan sebagai akibatnya dapat pula berstruktur keluar organisasi. Struktur yang terakhir jika organisasi tersebut melakukan interaksi dengan lingkungannya. ${ }^{18}$

Pola hubungan ini sesungguhnya memiliki legitimasi yang kuat pasca reformasi yang terjadi. Dengan adanya reformasi di bidang politik, hukum, dan perundang-undangan maka kedudukan DPRD dan Pemerintah Daerah saat ini mengalami perubahan yang mendasar dengan ditetapkannya Undang-Undang Nomor 32 tahun 2004. Fungsi DPR maupun DPRD sebagai wakil ada 3 (tiga) diantaranya pembentukan legitimasi adalah fungsi badan perwakilan atas nama rakyat berhadapan dengan Eksekutif. Badan inilah secara konstitusional membentuk citra demokratis pemerintah, sekaligus penentu stabilitas politik. Karena itu DPR maupun DPRD sebagai lembaga perwakilan terlalu pasif dan tidak pernah memberikan koreksi atau mengingatkan Eksekutif, justru mereka yang kehilangan legitimasinya

17Maswardi Rauf, Indonesia dan Komunikasi Politik, (Jakarta: PT. Gramedia Pustaka Utama, 1993), 29.

18Miftah Thoha, Perilaku Organisasi, (Jakarta: CV. Rajawali, 1993), 17. 


\section{Pembangunan Ekonomi Daerah}

Kota Cilegon dalam 15 tahun terakhir ini telah menjelma menjadi sebuah kota otonom yang tumbuh dan berkembang sangat pesat dan laju ekonominya sangat meningkat. Realisasi atas visi dan misi pembangunan sangat didukung oleh sejumlah indicator penting antara lain, geografis, Kota Cilegon adalah sebuah kota di Provinsi Banten, Indonesia. Cilegon berada di ujung barat laut pulau Jawa, di tepi Selat Sunda. Kota Cilegon dikenal sebagai kota industri. Sebutan lain bagi Kota Cilegon adalah Kota Baja mengingat kota ini merupakan penghasil baja terbesar di Asia Tenggara karena sekitar 6 juta ton baja dihasilkan tiap tahunnya di Kawasan Industri Krakatau Steel. Sementara secara demografi Kota Cilegon memilki kepadatan penduduk yang sangat ideal jika di ukur dari luas wilayah dan keberadaan tata ruang strategisnya, hal ini kita bisa lihat dari data statistik dan sensus terakhir penduduk.

Dalam Kurun Waktu 5 Tahun Terakhir (2010-2015) Jumlah Penduduk Kota Cilegon terus mengamali peningkatan yang sangat siginifikan, dari tahun ke tahun sebagaimana terlihat dalam table berikut ini:

Tabel. 2. Pertumbuhan Penduduk Kota Cilegon Tahun 2010-2015

\begin{tabular}{|l|l|c|c|}
\hline NO & TAHUN & $\begin{array}{c}\text { JUMLAH } \\
\text { PENDUDUK }\end{array}$ & $\begin{array}{c}\text { PERSENTASE } \\
\text { PENINGKATAN }\end{array}$ \\
\hline 1. & 2010 & 374.464 & $10,09 \%$ \\
\hline 2. & 2011 & 383.854 & $09.08 \%$ \\
\hline 3. & 2012 & 398.304 & $10,2 \%$ \\
\hline 4. & 2013 & 401.014 & $05,7 \%$ \\
\hline 5. & 2014 & 405.303 & $21,9 \%$ \\
\hline 6. & 2015 & 438.348 & $25,5 \%$ \\
\hline
\end{tabular}

Ket. Data diolah dari BPS Kota Cilegon

Tabel. 3. Jumlah Penduduk Kota Cilegon Tahun 2014 Jumlah Penduduk Menurut Jenis Kelamin dan Kecamatan Tahun 2014

\begin{tabular}{|c|c|}
\hline Kecamatan & Jenis Kelamin \\
\hline
\end{tabular}




\begin{tabular}{|l|l|l|l|}
\hline & \multicolumn{1}{|c|}{ Laki-Laki } & Perempuan & \\
\hline Ciwandan & 23633 & 22255 & 45888 \\
\hline Citangkil & 36498 & 34985 & 71483 \\
\hline Pulomerak & 22770 & 21911 & 44681 \\
\hline Purwakarta & 20499 & 19183 & 39682 \\
\hline Grogol & 21735 & 20769 & 42504 \\
\hline Cilegon & 21765 & 21034 & 42799 \\
\hline Jombang & 33188 & 31740 & 64928 \\
\hline Cibeber & 26914 & 26424 & 53338 \\
\hline Kota Cilegon & $\mathbf{2 0 7 0 0 2}$ & $\mathbf{1 9 8 3 0 1}$ & $\mathbf{4 0 5 3 0 3}$ \\
\hline
\end{tabular}

Sumber: Badan Pusat Statistik (BPS) Kota Cilegon

Masih cukup tingginya laju pertumbuhan penduduk di kota Cilegon tersebut terutama dipengaruhi oleh peristiwa migrasi masuk, disamping urbanisasi atas dampak dari pertumbuhan ekonomi dan peningkatan investasi modal yang dilakukan para investor.

Jika Pembangunan memiliki arti sebagai sebuah proses dimensional yang melibatkan berbagai perubahan besar di dalam struktur sosial, sikap2 mental yang terbiasa dan juga lembaga nasional termasuk pula akselerasi atau percepatan pertumbuhan ekonomi, pemberantasan dan pengurangan kemiskinan absolut. Maka apa yang terjadi dengan pembangunan ekonomi di kota Cilegon. Cilegon sebagai daerah tujuan investasi memiliki daya tarik bagi investor dalam dan luar negeri, hal ini dapat dilihat dari tingginya minat investor yang menanamkan modalnya di kota Cilegon.

Keberadaan industri di Kota Cilegon baik dalam rangka penanaman modal asing dan penanaman modal dalam negeri berdampak multiplier effect baik dalam pertumbuhan ekonomi kota Cilegon maupun penyerapan tenaga kerja dan sector lainnya. Kota Cilegon masih menjadi primadona sebagai daerah tujuan investasi 
karena didukung oleh berbagai faktor sarana dan infrasturuktur investasi. Kota Cilegon dengan luas lahan 17.550 Ha (175,50 Km2) tetapi ditunjang dengan sarana dan prasarana yang cukup memadai serta letak geografis yang sangat strategi. Kota Cilegon sebagai pintu gerbang pulau Jawa dan sumatera serta didukung oleh pelabuhan bertaraf internasional dan adanya pelabuhan khusus serta beberapa kawasan industri menjadikan kota Cilegon sebagai daerah tujuan invesatasi yang menarik bagi calon investor.

Data BPS tahun 2015 menunjukan sebuah kenyataan kongkrit bahwa pembangunan ekonomi berkelanjutan di kota Cilegon masih berlangsung, Tahun 2015, jumlah penduduk usia kerja Kota Cilegon sebesar 296.475 orang dimana 186.664 orang merupakan angkatan kerja dan 109.811 orang kelompok bukan angkatan kerja. Dari seluruh angkatan kerja terdapat 88,0 persen yang bekerja dan 12 persennya masuk kategori penganguran. Pendidikan orang yang bekerja sudah cukup baik dimana 60,1 persen sudah tamat SMA dan Akademi/perguruan tinggi dan masih ada sekitar 24,8 persen yang berpendidikan SD kebawah (tamat SD, tidak tamat SD atau tidak pernah sekolah sama sekali). Data ini menjadi gambaran bahwa efek dari pembangunan ekonomi berkelanjutan yang terjadi dikota cilegon sangat berdampak besar atas berkurangnya pengangguran serta angka pendidikan tamat sekolah meningkat. Itu artinya pembangunan ekonomi di kota Cilegon sedang berjalan

Momentum pertumbuhan ekonomi nasional menjadi peluang bagi peningkatan kinerja perekonomian daerah termasuk Kota Cilegon sendiri. Oleh sebab itu, dalam upaya memanfaatkan momentum dan peluang pertumbuhan ekonomi nasional dan daerah, berbagai kebijakan, program dan kegiatan yang direncanakan pada tahun 2015 diarahkan untuk memacu peningkatan produktivitas daerah dan penciptaan pertumbuhan yang lebih berkualitas.

Pertumbuhan ekonomi diharapkan, tidak hanya, mampu mendorong peningkatan kapasitas produksi, penciptaan lapangan kerja baru dan pengurangan kemiskinan, tetapi juga pengurangan 
kesenjangan antar daerah dan antar kelompok masyarakat. Kota Cilegon memiliki sejumlah potensi stategis untuk mempercepat pembangunan ekonomi daerahnya secara baik dan konsisten. Secara geografis, kependudukan, demografi, sosial, budaya dan politik. Untuk itulah sejumlah rencana dan rancangan berbagai kebijakan pemerintah diarahkan pada usaha mempercepat pembangunan itu. Khusus untuk tahun 2015 pemerintah kota Cilegon telah merancang dan mengarahkan program prioritas pembangunan daerah yang termuat program-program yang berorientasi pada pemenuhan hak-hak dasar masyarakat dan pencapaian sasaran dari RPJMD Pemerintah Kota Cilegon untuk periode tahun 2015, dan isu-isu global serta menjawab setiap permasalahan yang muncul sesuai dengan kondisi terakhir di Kota Cilegon

Pembangunan daerah Kota Cilegon pada tahun 2015, dilaksanakan sebagai lanjutan pembangunan tahun-tahun sebelumnya dan merupakan jawaban atas permasalahan yang berkembang saat ini, maka prioritas-prioritas pembangunan tahun 2015 adalah prioritas yang terdapat dalam RPJMD Periode Tahun 2010-2015 yang difokuskan pada penyelesaian terhadap masalahmasalah yang mendesak dan berdampak luas terhadap peningkatan perekonomian masyarakat, peningkatan sumberdaya manusia melalui pendidikan dan kesehatan, pelaksanaan pemerintahan yang baik, peningkatan dan perbaikan infrastruktur yang mendorong pengembangan kawasan dan pariwisata serta penanggulangan bencana dan pelestarian lingkungan hidup yang ditujukan untuk kesejahteraan rakyat.

Beberapa potensi yang dapat dimaksimalkan oleh pemerintah kota Cilegon untuk memacu dan mendokrak pembangunan ekonomi daerahnya antara lain:

a. Dalam Rencana Tata Ruang Wilayah (RTRW) Provinsi Banten Tahun 2002-2017, Kota Cilegon lebih diarahkan pada pengembangan kelompok industri besar dan sedang, industri kecil, dan industri kerajinan. 
b. Kota Cilegon sebagai simpul sistem jaringan utilitas dan pergerakan Jawa-Sumatera.

c. Kota Cilegon sebagai potensi inlet-outlet terhadap lokasi pasar dunia.

Atas dasar semua potensi ekonomi tersebut diatas sangat wajar jika kota Cilegon sangat mendapat sorotan baik dalam skala kewilayahan maupun dalam lingkup nasional atas beberapa rencana strateginya dalam pembangunan maupun dalam keberhasilannya dalam pembangunan. Keberhasilan dalam pembangunan dapat di lihat selama kurun waktu periode RPJM 2010-2015.

Indikasi yang menunjukan keberhasilan itu antara lain di dukung oleh fakta Keberhasilan Pembangunan bidang perekonomian dicerminkan dari erkembangan indikator PDRB (Product Domestic Regional Bruto) dan LPE (Laju Pertumbuhan Ekonomi), yang mengindikasikan perbaikan, penguatan dan kemapanan daerah dalam penguatan struktur perekonomian daerah. Laju Pertumbuhan Ekonomi Kota Cilegon meningkat mencapai 5,30 Trilyun Pada Tahun 2010 menjadi 6,82 Trilyun pada tahun 2012. Pada tahun 2009 PDRB Kota Cilegon mencapai Rp 51 juta/kapita dan melebihi angka rata-rata pendapatan perkapita masyarakat Indonesia pada umumnya. Hal ini dikarenakan Kota Cilegon ditopang oleh sektor perindustrian berat yang bertumpu pada penggunaan teknologi dan kimia dan bukan berbasis pada industri manufaktur ringan.

Pada akhir tahun 2010, Krakatau Steel sebagai perusahaan pelat merah yang berproduksi di Cilegon menggandeng perusahaan asal Korea Selatan, POSCO untuk melaksanakan joint venture di Kawasan Industrial Krakatau. Seiring dengan bertambahnya investasi asing melalui penanaman modal langsung di Cilegon, telah terjadi peningkatan perekonomian yang berarti dengan meningkatnya indikator PDRB di Kota Cilegon.

Dari berbagai geliat pembangunan ekonomi yang terjadi dikota cilegon tersebut dapatlah disimpulkan bahwa pertumbuhan 
ekonomi dalam lima tahun terakhir di Kota Cilegon rata-rata 4.5 persen, maka penurunan angka kemiskinan Kota Cilegon sebesar 1.2 persen pertahun, atau turun sebesar 6 persen dibandingkan tahun 2010. Data ini didasarkan pada analisis dalam Sensus Ekonomi 2015 yang dilakukan oleh Badan Pusat Statistik (BPS), di mana angka kemiskinan Kota Cilegon menunjukan penurunan yang sangat dramatis, yaitu sebesar 3.85 persen dari total jumlah penduduk tahun 2015.

Apa yang tergambar dalam angka-angka statistik yang ditampilkan di atas tentang peningkatan pembangunan ekonomi kota cilegon, merupakan andil besar dan peran penting dan sinergisitas yang kuat antara kelembagaan parlemen dalam mengembankan kapasitasnya sebagai lembaga legislatif dengan pemerintahan daerah sebagai lembaga eksekutif. Hal ini karena pembangunan ekonomi berkaitan langsung dengan keseluruhan proses politik, budaya, dan ekonomi yang diperlukan untuk mempengaruhi transformasi struktural dan kelembagaan yang cepat dari seluruh masyarakat melalui proses yang efisien demi menghasilkan rentetan kemajuan ekonomi yang benar-benar bermanfaat bagi masyarakat.

Dalam proses politik sendiri memungkinkan terbentuknya polarisasi kegiatan dalam system pembangunan dalam sebuah negara atau daerah melalui pembagian-pembagian kekuasan atau pendapatan untuk mencapai tujuan yang telah disepakati. Dunia politik sangat berpengaruh terhadap kemajuan ekonomi suatu bangsa atau daerah. Dalam pengembangan ekonomi, sangatlah penting mempertimbangkan risiko politik dan pengaruhnya terhadap kelangsungan ekonomi. Untuk itu kebijakan politik yang dibangun dapat diintegrasikan pula dalam perspektif hukum sehingga akan didapat gagasan dan kebijakan yang dirumuskannya dapat berdampak pada peningkatan pembangunan ekonomi itu sendiri.

Keberadaan sistem politik yang jelas dan jaminan kepastian hukum akan berdampak pada meningkanya laju pembangunan 
ekonomi. Kombinasi antar keduanya sesungguhnya pilar utama penggerak bagi terciptanya peningkatan pembangunan ekonomi, demikianlah apa yang sesungguhnya terjadi di kota Cilegon. Saat dimana kondisi politik yang sangat stabil dan baik akan mempermudah proses lahirnya suatu produk hukum berupa peraturan yang mendukung terhadap terbitnya sebuah kebijakan sebagai bagian dari upaya mendorong lajunya pertumbuhan dan peningkatan pembangunan ekonomi kota Cilegon.

Pada akhirnya kondisi perekonomian suatu daerah akan bisa tumbuh dan meningkat apabila pemerintah tetap berperan sebagai partner yang menguntungkan bagi berkembangnya usaha dan investasi atas upaya peningkatan pembangunan ekonomi dan semua itu dipengaruhi oleh kondisi politik dalam negeri. Perangkat-perangkat kebijakan politik dan beberapa produk hukum perlu di dorong secara lebih baik lagi untuk memberikan jaminan investasi dan diperlukan pula inovasi gagasan dan mekanisme hubungan kerja antar perangkat, daerah dalam satuan kerja yang ada serta mental birokrasi dengan harapan mampu mendukung pemerintah daearah untuk meninkatkan pembangunan ekonomi daerahnya.

\section{Penutup}

Kebijakan politik hukum yang dilakukan oleh Pemerintah Kota Cilegon dapat mendorong atas terjadinya peningkatan pembangunan ekonomi daerah, hal ini terlihat dari produk legislasi yang disahkan oleh DPRD Kota Cilegon secara kualitas dan kuantitas sudah sangat baik sehingga produk tersebut dapat dilaksanakan dengan baik oleh eksekutif dan memberikan kekuatan yuridis bagi Pemerintah Kota Cilegon dalam peningkatan pembangunan, sebagaimana terlihat dari indikator peningkatan pembangunan yang ada di Kota Cilegon itu sendiri.

Kebijakan politik hukum yang diolah dan diproses secara sinergis antar lembaga-lembaga pemerintahan yang ada di Kota Cilegon, mengindikasikan komitmen yang kuat dan besar dari 
lembaga-lembaga tersebut untuk mendorong dan meningkatkan kesejahteraan rakyat secara berkesinambungan dan terukur. Atas upaya mewujudkan visi, misi dan tujuan yang telah dirancangnya dalam RPJP tahun 2010-2025 dan di lakukan evaluasi dalam RPJM tahun 2010-2015 secara berkala, memberi kesan atas komitmen kebersamaannya untuk terus meningkatkan pembangunan ekonomi dan kesejahteraan rakyat secara baik.

\section{Daftar Pustaka}

Abdul Solichin, Wahab. Analisis Kebijakan, dari Formulasi ke Penyusunan Model-Model Implementasi Kebijakan Publik. Jakarta: Bumi Aksara, 2001.

Agustion, Leo. Dasar-Dasar Kebijakan Publik. Bandung: Alfabet, 2008. Arifin, Tahir. Kebijakan Publik \& Transparansi Penyelenggaran Pemerintah Daerah. Bandung: Penerbit Alfabeta, 2014.

Arrsa, Ria Casmi. "Restorasi Politik Legislasi Pembentukan

Peraturan Daerah Berbasis Riset". Jurnal Rechts Vinding, Media Pembinaan Hukum Nasional, Volume 2 Nomer 3 Desember 2013.

Dunn, Willian N. Pengantar Analisis Kebijakan Publik. Edisi Revisi, Yogyakarta: Gajah Mada University, 2003.

Fahrudin, Adi. Pengantar Kesejahteraan Sosial. Bandung: Refika Aditama, Mei 2014.

Hartono, Sunaryati. Politik Hukum Menuju Satu Sistem Hukum Nasional. Bandung: Alumni, 1991.

Kartasasmita, Ginanjar. Pembangunan Untuk Rakyat; Memadukan Pertumbuhan dan Pemerataan. Jakarta: Pustaka Cresindo, 1996.

Kuncoro, Mudrajat. Ekonomi Pembangunan, Teori Masalah dan Kebijakan. Yogyakarta: AMP YKPN, , 2003.

Manan, Bagir. Menyongsong Fajar Otonomi Daerah. Yogyakarta: PSH FH UII, 2001.

Massei, Inri. "Kajian Hukum Terhadap Kebijakan Pemerintah Kota Manado Dalam Pengelolaan Tata Perekonomian Terhadap 
Kesejahteraan Rakyat". Jurnal Lex Et Societatis, Vol.III No.2 Maret 2015, Edisi Khusus.

MD, Moh. Mahfud. Membangun Politik Menegakkan Konstitusi. Depok: Rajawali Pers, 2010. 2011.

. Politik Hukum di Indonesia. Depok: Rajawali Pers, Cet.4,

Midgley, James. Pembangunan Sosial, Perspektif Pembagunan dalam Kesejahteraan Sosial. Jakarta: Deperta Depag RI, 2005.

Misdyanti, dan R.G. Kartasapoetro. Fungsi Pemerintah Daerah Dalam pembuatan Peraturan Daerah. Jakarta: Bumi Aksara, 1993.

Muhadjir, Noeng. Kebijakan dan Perencanaan Sosial; Pengembangan Sumber Daya Manusia. Yogyakarta: Rake Sarasin, 2000. . Metodologi Penelitian Kebijakan dan Evaluation Research. Yogyakarta: Rake Sarasin, 2004.

Nugroho, Iwan dan Rokhimin Dahuri. Pembangunan Wilayah Perspektif Ekonomi, Sosial, dan Lingkungan. Jakarta: LP3ES, 2004. Raharjo, Satjipto. Ilmu Hukum. Bandung: Citra Aditya Bakti, 2000.

Rasyid, M. Ryaas. Otonomi Daerah Dalam Negara Kesatuan. Yogyakarta: Pustaka Pelajar, 2002.

Rauf, Maswardi. Indonesia dan Komunikasi Politik. Jakarta: Gramedia Pustaka Utama, 1993.

Safril, dkk. Ekonomi dan Pembangunan. Jakarta: Bumi Aksara, 2003. Sanit, Arbi. Sistem Politik Indonesial Kestabilan, Peta Kekuatan Politik dan Pembangunan. Jakarta: Raja Grafindo Persada, 2012.

Saraswati, Retno. "Arah Politik Hukum Pengaturan Desa Ke Depan”. Jurnal Masalah-Masalah Hukum, Jilid 43 No.3 Juli 2014. Subandi. Ekonomi Pembangunan. Bandung: Alfabeta, Cet. Ke-4., 2016. Suharto, Edi. Membangun Masyarakat Memberdayakan Masyarkat; Kajian Strategis Pembengunan Kesejahteraan Sosial dan Pekerjaan Sosial. Bandung: Refika Aditama, 2009. . Pembangunan, Kebijakan Sosial dan Pekerjaan Sosial: Spektrum Pemikiran. Bandung: LSP-STKS, 1997.

Sukirno, Sadono. Ekonomi Pembangunan. Jakarta: LPEF-UI Bima Grafika, 1985. 
T Sumarno, Nugroho. Sistem Intervensi Kesejahteraan Sosial. Yogyakarta: Hanidinta, 1987.

Thaib, Dahlan. DPRD Sistem Ketatanegaran Indonesia. Yogyakarta: Liberty, 1994.

Thoha, Miftah. Perilaku Organisasi. Jakarta: CV. Rajawali, 1983.

Todaro, Michel. Pembangunan Ekonomi Didunia Ketiga Edisi Ke Tujuh. Jakarta: Balai Aksara, 2010.

Wahab, Abdul Solichin. Analisis Kebijakan, dari Formulasi ke Penyusunan Model-model Implementasi Kebijakan Publik. Jakarta: Bumi Aksara, 2012.

Wahyono, Padmo. Indonesia Negara Berdasatkan Atas Hukum. Jakarta: Ghalia Indonesia, Cet. II, 1986.

Widjaya, HAW. Penyelenggaraan Otonomi di Indonesia. Jakarta: Raja Grafindo Persada, 2009.

Winarno, Budi. Teori dan Proses Kebijakan Publik. Yogyakarta: Media Pressindo, 2012. 